\title{
Cultural Influence in the Practice of Corporate Governance in Emerging Markets
}

\author{
Vahideh Baradaran Rafiee ${ }^{1}$ and Jawahitha Sarabdeen ${ }^{2}$ \\ ${ }^{1}$ Faculty Member of Business Management Department Islamic Azad University, Dubai, \\ United Arab Emirates \\ ${ }^{2}$ Associate Professor, Faculty of Business \& Management, University of Wollongong in Dubai, \\ United Arab Emirates
}

\begin{abstract}
Corporate governance seeks to ensure a fair return on the investment and it also establishes incentives and procedures that meet the interests of shareholders while respecting other stakeholders' interests in the organization. Corporate governance has become one of the hottest topics of discussion in the circle of regulators, practitioners and academic in the aftermath of recent financial crisis. The financial crisis pint points the lack of corporate governance practice and that many institutions have taken heed to ensure compliance of corporate governance to win back the confidence of investors and regulators. Well-developed theories like agency theory, stewardship theory, hegemony theory and transaction cost theory could be used to understand the concept of corporate governance. The aims of this research are to anlayse the concept of corporate governance and see the level of adherence to corporate governance in emerging economies. The research also endeavors to link the cultural influence in the adoption of corporate governance. As there are only limited researches so far on the corporate governance and related issues in emerging markets, this research would contribute to the existing knowledge by filling the gap on corporate governance in emerging markets.
\end{abstract}

Keywords: Corporate Governance, Culture, Emerging Market.

\section{Introduction}

There is limited research on corporate governance practice in developing countries. Interest in corporate governance is rapidly increasing inside and outside academia. The recent economic crisis, financial scandals and collapse of many companies in the developed and developing markets have attracted the attentions of researchers and business people to improve the corporate governance practices.

International bodies such as OECD (Organization for Economic Co-operation and Development), has examined various member and non-member countries to evaluate their corporate governance systems and to provide suggestions for corporations, shareholders, and other stakeholders who play important roles in improving corporate governance systems. The principles developed by OECD are considered essential for the development of corporate governance systems. However, there are various barriers to effective implementation of corporate governance principles.

Considering the importance of developing countries to the future of the world economy, the focus of this paper is on the cultural influences in adopting effective corporate

Copyright (C) 2012 Vahideh Baradaran Rafiee and Jawahitha Sarabdeen. This is an open access article distributed under the Creative Commons Attribution License unported 3.0, which permits unrestricted use, distribution, and reproduction in any medium, provided that original work is properly cited. Contact author: Vahideh Baradaran Rafiee E-mail: baradaran@iau.ae 
governance practices in these countries. This study will initially explore the theoretical background of the corporate governance and the culture influence in adoption of corporate governance. The paper also explores the problems with corporate governance systems in developing countries in general and it discusses how national culture influences corporate governance practices.

\section{Theoretical Framework}

This section analyses corporate governance, culture and the relationship between various cultural dimensions and corporate governance.

\section{Corporate Governance}

According to Shleifer and Vishny (1997) corporate governance is the ways in which providers of finance ensure themselves a return on their investment. Reed (2002) states that corporate governance establishes incentives and procedures that meets the interests of shareholders while respecting other stakeholders' interests in the organization. Ananchotikul and Eichengreen (2009) suggest corporate governance plays three critical roles. They state that corporate governance facilitates and enhances corporations' performance by providing incentives that act as motivation factors to the corporations' managers and employees so as to improve efficiency of operation, return on investment as well as achieve sustained growth and development. In addition, they state that effective corporate governance prevents embezzlement of corporate resources by the managers as well as limit them from abusing their powers. Moreover, they suggest that corporate governance gives a means of monitoring the behaviors of managers so as to enhance corporation accountability as well as provision of a cost effective way of protecting the interests of the shareholders and the society at large against those of the corporate insiders.
There are a number of well-developed theories that aid researchers in exploring the corporate governance issue. Agency theory, stewardship theory, hegemony theory and transaction cost theory are some of the well known theories in this field. Agency theory has been extensively used in explaining the conflict of interest between investors as the principles and the managers as agents (Jensen \& Meckling 1976). This theory implies that agents will be driven by self interest rather than willingness to maximize the profit for shareholders. In order to solve this problem an independent board of director is expected to solve this problem (Shleifer \& Vishny, 1996). Agency theory suggests mechanism that rewards managers for maximizing shareholders profit. Such schemes typically include plans whereby executive managers obtain reduced price shares to align the interest of managers with those of shareholders.

Transaction cost theory is another theory that is used in the discussion of corporate governance. This theory first originated from Coase's (1937) work and later developed by Williamson who asserted that the purpose of governance is to recognize, clarify and mitigate all forms of contractual hazards. The main purpose of governance according to the transaction cost theory is "to clarify the carrying out of economic transactions by the efficiency of the chosen governance structures that have been adapted to carry out the transactions at hand" (1996, p.5). As per this theory, effective and efficient performance of transaction by adopting formal and informal structure and rules are important than protection of ownership rights of shareholders. The transaction cost theory discusses 2 types of governances. They are Market Governance and Governance through Hierarchies. Market Governance advocates strict adherence to rules of contract and rely on high-powered incentives to control managerial opportunism and induce managers to take appropriate action. The Governance through 
Hierarchies introduces monitoring and administrative mechanism as a form of corporate governance (McClelland \& O’Brien, 2011).

On the contrary to the agency theory, the stewardship theory put forward by Donaldson and Barney (1990) is a view that managers are motivated by intrinsic desire for achievement and are ready for challenges. They have a desire to do the jobs right and to be a good steward of the corporate assets. Thus, stewardship theory holds that the CEO's are naturally motivated. A further theory in the field of corporate governance is managerial hegemony theory that suggests boards of directors are statutory additions that are controlled by managers and they only play a passive role in strategy or directing corporation (Mace, 1971; Vance, 1983).

Various scholars worked on different aspects of corporate governance and they have examined corporate governance from different country perspectives. Li \& Harrison (2007) focus on the different source of finance across country and examine the difference between financing from banks and financing from capital market and its impact on the structure of corporate governance. With regards to the source of finance, countries have been classified into bankcentered (banks are the provider of finance to the companies such as Germany and Japan) and capital market (capital market is the source of the finance for the companies like United Kingdom and United states) and examines the difference between the two systems in term of practices of corporate governance (Allen \& Gale, 2000).

\section{National Culture}

Kroeber and Kluckhohn (1952) suggest culture is a vague concept and it implies multiple meanings. A well accepted definition of culture is by Dutch researcher Geert Hofstede (1984):
"Culture is the collective programming of the mind which distinguishes the members of one group or society from those of another. Culture consists of the patterns of thinking that parents transfer to their children, teachers to their students, friends to their friends, leaders to their followers, and followers to their leaders. Culture is reflected in the meanings people attach to various aspects of life; their way of looking at the world and their role in it; in their values, that is, in what they consider as 'good' and 'evil'; in their collective beliefs, what they consider as 'true' and as 'false'; in their artistic expression, what they consider as beautiful' and as 'ugly'."

As this definition implies, values are considered as the most fundamental aspect of culture. To understand a culture thoroughly, it is essential to understand its cultural values. Values form attitudes which respectively, shape the people's behavior. Cultural values shape the behavior of all the individuals in the society and social environment as a whole.

Many scholars developed various frameworks to understand national cultures. Usually, these frameworks consist of several dimensions which are used to explain cross cultural differences internationally. Cultural values can be measures as for each dimension two extreme value are specified and each countries cultural value can be measured accordingly. To illustrate, Rokeach value survey (Thompson, 1982), Schwartz's cultural value dimension (Schwarts, 1999) have developed frameworks to explore the different components of culture. The two most recognized theory of culture are developed by Hofstede (1994) and Schwartz (2001).

Hofstede states societies' culture can be analyzed across different dimensions including, Power Distance Index (PDI), Individualism Index (IDV), Masculinity (MAS) and Uncertainity Avoidance Index (UAI). 
Hofstede added one more dimension to his theory later which is, Long-term Orientation (LTO).

Although, Hofstede's theoretical framework has been accepted by many scholars internationally to explain cultural differences, Schwartz's framework seems also eligible as he tries to overcome some problems with Hofstede's model. He tried to develop a more comprehensive framework that has been empirically validated. He derived his framework from three basic problems that confront societies including; the nature of the relation between individuals and groups, encouraging responsible behavior to safeguard the social structure and the management of social and natural work. The Schwartz cultural model identifies three bipolar dimensions to deal with these problems including, Embeddedness versus autonomy, Hierarchy versus Egalitarianism, and Mastery versus Harmony.

Schwartz suggests embeddedness focuses the maintenance of status quo and relies on values such as order, respect for traditions, reciprocation of favor and wisdom. He explains autonomy relates to individual willingness for independency and pursuing their ideas. He describes the hierarchy dimension of culture as unequal distribution of power. Moreover, egalitarianism is explained as showing concern for every individual's welfare and emphasizes on values like social justice, equality, responsibility and helpfulness.

\section{Comparison of Hofstede and Schwartz Cultural Dimension}

Hofstede and Schwartz explain the cultural dimensions in a comprehensive manner. Despite some conceptual differences, the cultural dimensions by Hofstede and Schwartz demonstrate some similarities.

Salzmann and Breuer (2005) compare and contrast Hofstede and Schwartz cultural dimensions. They illustrate that Individualism and Collectivism have common characteristics with Autonomy versus Embededness, since both explain the relationship between individual and group. The difference would be the values like social order and freedom are not explained by individualism and collectivism. Another dimension of Hofstede; Power Distance, which explains the level of inequality in a society overlaps with Hierarchy versus Egalitarianism in Schwartz model. However, the values such as social justice and social power are not explained in Hofstede model. Masculinity and Feminity explain the distribution of roles between male and female. Masculinity and Feminity might be related to Mastery as both emphasize assertiveness, activity and ambition. However, Mastery does not include a contrast to feminine values. Uncertainty Avoidance is another dimension of Hofstede's cultural dimension which is the tolerance level of the society for uncertainty and ambiguity and refers to individual's search for truth. Uncertainty Avoidance is comparable with Harmony dimension of Schwartz's model as both advocate harmony and order. The difference between these two dimensions is harmony refers to fitting into nature, whereas Uncertainty Avoidance refers to harmony by a vigorous control of uncertainty.

\section{Corporate Governance Predicaments in Emerging Markets}

Corporate governance systems have been considered a significant factor in economic development of countries. The main aim of corporate governance is to manage the company towards success and corporate accountability with the objective of enhancing shareholders value and protecting the long-term interests of stakeholders. According to Chan and Cheung (2008) emerging markets are the markets with newly developed financial market, a short operating history, a smaller capital market and lower trading volume. 
Over the last two decades, corporate governance has gained tremendous attention from academia and the business world. The increasing attention is due to questionable practices and scandals of companies. In addition, as Reed (2002) suggests that poor economic performance of developing countries which is blamed on weak corporate governance may trigger financial crisis in certain regions. As a result, international financial organizations such as IMF and the World Bank are closely examining the corporate governance systems in developing countries. The pressure of globalization and the fact that more investors turns to equity investment internationally, have led companies of emerging markets towards a comprehensive reform to adopt corporate governance practices.

The quality of corporate governance is more important to emerging market, as these countries need to attract foreign direct investment (FDI) to further develop their economies. In addition, companies operating in developing countries need to improve their corporate governance systems, in order to decrease their cost of capital. According to Cadbury (1999) increasingly, institutional investors, banks, mutual funds, base their decision on the reputation and corporate governance quality. He points out that sound systems of corporate governance attracts more domestic as well as international investors.

The Organization for Economic Co-operation and Development (OECD) has set up international corporate governance benchmark principles for investors, governments, corporations and other stakeholders. However, the implementation of these principles in emerging markets is particularly challenging. Many emerging economies lack the institutional and human requirements that are critical to the implementation of corporate governance principles. There are various institutional, economical, political, social and cultural barriers to the effective implementation of
OECD's corporate governance principles in developing countries.' According to Okpara, lack of adequate regulatory system, weak protection of share holders' right, lack of law enforcement and monitoring are main reasons for ineffectiveness of governance system in developing countries. Miller et al. (2005) states lack of transparency and ineffective board of directors are the main reasons for corporate governance inefficiencies.

Few researchers have explored the problems with corporate governance in emerging markets. The main problem of corporate governance is explained by Shellfire and Vishny (1986). They put forward the "Agency theory" to explain the conflict of interest between shareholders and managers. They argue that shareholders are interested in increasing their share value. However, managers wish to maximize their power and wealth which leads to problems in corporate governance. Poker (2011) suggest that managers are interested to disclose information if the company is performing well to receive bonuses and incentives. The Agency problem and the need for an independent board is more significant in emerging market as majority shareholders of corporations are family and boards can become redundant when activist shareholders are family or government(Turnbull, 1997).

Adequate regulatory system to protect shareholders' right is a major consideration to improve the government system in emerging markets. Although, boards of directors are assigned to manage the company, the shareholders have some influence on corporations' policy. Shareholders have a percentage of votes in proportions to their shares. If shareholders think the management is performing poorly they can elect a new board of director and subsequently a new management. However, truthful board elections are rare. Board members are usually selected by other member of the board or management. 
Okpara (2011) suggests shareholders' rights are different across countries. Jiraporn and Davidson (2009) examined the strength of the shareholders rights by measuring the number of restrictive governance provisions that restrain the shareholders right.

Okpara (2011) states that the major problem in developing countries is the lack of protection of minority shareholders. He explains even though there are countries that introduced laws to protect the right of shareholders, there is no enforcement system. He also points out that the shareholder's lack of knowledge regarding their rights is another major issue in these countries. La Porta et al. (1997, 1998) proposed an index to measure the legal protection to investors. Many researchers have worked to examine the scope of legal protection provided to investors across countries and especially in emerging markets and their effects on corporate governance performance.

The lack of transparency and publicly available information is another major problem with emerging markets. Millar et al. (2005) point out that the cost of investing increases in countries where the level of transparency is low. After Enron and WorldCom corporate scandals the SarbanesOxley Act (SOX) was adopted that requires company to disclose detailed information regarding company financial statements. The Cadbury Report (1992) argues there is a danger in disclosing information that some companies may disclose incomplete or distorted information to mislead and confuse public as well as shareholders. Okpara (2011) empasises the importance of credible disclosure of corporate information.

A high concentration of corporate ownership and family control is another fundamental problem of corporate governance in emerging market. Millar et al (2005) argues that dominant family shareholders make the important decisions independently. They appoint the board members and there is a possible conflict of interest between managers, minority shareholders and them. Poker (2011) suggests that controlling shareholder may collude with managers to impound minority shareholder's benefit particularly in developing countries with limited shareholders protection. Mork et al. (2000) also explain majority shareholders may follow objectives that are in conflict with those of minority shareholders. However, large shareholders may benefit minority shareholders as they are able to prevent the asset expropriation by managers. Thus, the relationship between the concentration of ownership and corporate governance efficiency is intricate.

Another problem with corporate governance in developing country is restriction of competition. Barriers to competition vary from anti-competitive practices by companies to entry restrictions. Khemani \& Leechor (1999) suggest that entry impediments are normally disguised to regulations that purportedly protect the public interest. They suggest the lack of competition increases the concentration of ownership.

Cadbury (1999) points out the challenges in implementation of corporate governance principles are mainly due to complexity of ownership structure. He introduces the intertwining relationships between government, financial sector and corporation as a major challenge. In addition, a common pattern in the ownership structure of companies in developing countries is the dominance of institutional and family own businesses. Cadbury (1999) states, while this ownership pattern allows tight control of the firm, it also expropriate outside shareholders. Another problem with effective execution of successful corporate governance in regards to ownership structure is the massive privatization trends that has led to creation of new corporations that lack the legal and institutional structures required to operate in a global market.

Emerging markets lacks the fundamental elements needed to operate in a competitive 
market and there is no culture of compliance and enforcement. Insufficient competition strategy discourages new businesses to emerging market. In addition, the ambiguous laws and regulations and weak supervisory system deteriorate the quality of corporate governance. According to Setiawan (2007) outdated contract and insolvency laws hinder efficient operation and timely exit. Sometimes even if the laws are updated the enforcement are uneven and selective indicating misuse of official power. The malpractices of regulatory systems affect the creditworthy of the companies in emerging markets. Consequently, the institutional investors are reluctant to invest in these companies.

\section{The Impact of Culture on Corporate Governance}

Corporate governance plays an important role in creating a sound relationship between managers, shareholders, board of directors and other stakeholders. According to Cheung \& Chan, (2007), understanding cultural differences among different nations is significantly important as different nationalities solve their problems, interact with each other and run their businesses differently. The quality of corporate governance depends highly on the effective interaction and negotiation among concerned parties. According to Chan and Cheung (2008) culture plays an important role in establishing a productive negotiation among people.

There are various studies to explore the relationships between national culture and corporate governance. Licht (2001) states culture influences the organizational policies through the values held by decision makers. He suggests culture contributes to the interpersonal relationship of individuals and institutions relationships and consequently changes the choice of corporate governance structure.

Licht, Goldschmidt, \& Schwartz (2004) study the effects of culture on three social norm of governance. They are: the rule of law, noncorruption level, and democratic accountability. La Porta, Lopez-de-Silanes, Shleifer, \& Vishny (1998) also found a noteworthy relationship between legal system and culture.

Various studies have been conducted to examine the relationship between culture and corporate governance. Salzmann \& Breuer (2005) state differences on investors' objectives, ownership structure, corporate boards and hostile takeovers and protection of minority shareholders are the reasons for the differences in corporate governance systems across countries. De Jong \& Semenov (2006) explain significant relationships between corporate control, ownership structure, protection of minority shareholders and cultural dimension of Hofstede. Li \& Harrison (2008) used Hofstede model to explain the structure of corporate boards.

\section{The Implication of Culture in Adopting Corporate Governance}

The power distance dimension of culture proposed by Hofstede has implication in effective adoption of corporate governance in emerging markets. In emerging markets, power has been distributed unequally among the member of the society. In societies with high power distance ordinary people are afraid of disagreeing with managers and they comply with managers decisions (Hofstede, 1984). In contrast, societies with low PDI people are more willing to disagree with authorities. In addition, managers in this kind of societies ask for the opinions of those at the lower levels. In low power distance culture, people think everyone should be treated in the same way and executives should not take advantage of them. According to Chan \& Cheung (2008) it is harder to accomplish good corporate governance practices through negotiation when there is a big inequality gap between powerful and ordinary people. Thus, low PDI countries would have high overall corporate governance practices compare to the high 
PDI countries. The main reason is that the managers need to satisfy the demands of the investors to attract investment and to establish a balance between powerful and powerless. The other aspect of cultural dimension is Individualism Index (IDV).

Countries where rated as high in IDV, people focus on them and give personal thought before investment. They are less influenced by any group or community decisions. Demand for more information, transparency and good financial performance are common in this culture. Therefore, good corporate governance is a norm in industries. Countries where IDV is low, the investors and managers are influenced by traditional authorities, roles and social duties. The level of Uncertainty Avoidance Index (UAI) and Masculinity (MAS) also determine the effectiveness of corporate governance. Low in UAI tells that the community is less tolerance to uncertainty and stakeholders are open for change and good corporate governance. In high UAI, it is easy to notice strong desire to follow the existing corporate set up. This community is conservative and obeys the social system. It will be difficult to make changes to implement better corporate governance. In the dimension of MAS, if a country displays less in MAS, the managers treat them as ordinary employees and concerned about social welfare. In this type of country, good corporate governance is common.

As most of the emerging market falls on high PDI, low on IDV (Collectivist), high in UAI and low in MAS as per Hofstede classification of cultural dimensions, it is common to notice weak corporate governance practices. In order to attract investors and to be reliable, it is important to create a good corporate culture of corporate governance and to introduce effective regulatory mechanism.

\section{Conclusion}

Corporate governance has increasingly attracted the attentions of scholars and business people. Recent corporate governance scandals at prominent companies have shaken the confidence of the investors. Emerging markets are extensively known for their poor corporate governance. Numerous researches have attempted to

explain the barriers to implementation of effective corporate governance in these countries. Almost all the researches acknowledge the impact of the national culture on effective implementation of the corporate governance. The quality of corporate governance is more important to countries in emerging markets as these countries are in desperate need for foreign investment to improve their economic growth. Many scholars have tried to explain the national culture and its impact on corporate governance. Various studies have attempted to examine the impact of culture on corporate governance system by applying Hofstede's and Schwartz's cultural models. All the studies indicate a strong correlation between national culture and corporate governance system. As most of the emerging market falls on high PDI, low on IDV (Collectivist), high in UAI and low in MAS as per Hofstede classification of cultural dimensions, it is common to notice weak corporate governance practices thus adoption of good corporate governance is imperative to attract investors.

\section{References}

Allen, F. \& Gale, D. (2000). Comparing Financial Systems, Cambridge, MA: MIT Press.

Barney, J. B. (1990). "The Debate between Traditional Management Theory and Organizational Economics: Substantive Differences Or Intergroup Conflict?," Academy of Management Review,15(3), 382393.

Cadbury, A. (1999). "What Are the Trends In Corporate Governance? How Will They Impact Your Company?," Long Range Planning, 32(1),12-19.

Chan, A. W. \& Cheung, H. Y. (2008). "Common Cultural Relationships in Corporate 
Governance across Developed and Emerging Financial Markets," Applied Psychology: an International Review, 57(2), 225-245.

Cheung, H. Y. \& Chan, A. W. H. (2007). "How Culture Affects Female Inequality across Countries: An Empirical Study," Journal of Studies In International Education, 11(2), 157-179.

Coase, R. H. (1937). "The Nature of the Firm," Economica 4(16):386-405.

De Jong, E. \&, Semenov, R. (2006). "Cultural Determinants of Ownership Concentration across Countries," International Journal of Business Governance and Ethics, 2(1), 145165.

Donaldson, L. (1990). “The Ethereal Hand: Organizational Economics and Management Theory," Academy of Management Review, 15(3), 369-381.

Hofstede, G. (1994). 'Values Survey Module. Maastricht, the Netherlands: Institute for Research on Intercultural Cooperation,'

Hofstede, G. H. (1984). Culture's Consequences: International Differences in Work-Related Values, Sage, London.

Jenson, M. C. \& Meckling, W. H. (1976). "Theory of the Firm: Managerial Behavior, Agency Costs, and Ownership Structure," Journal of Financial Economics, 3(4), 305-360.

Jiraporn, P. \& Davidson, W. (2009). "Regulation, Shareholder Rights and Corporate Governance: An Empirical Note," Applied Economic Letter, 16(10), 977-982.

Khemani, R. S. \& Leechor, C. (1999). "Competition Boost Corporate Governance," The World Bank, Available at: http://planningcommission.gov.in/aboutus/ committee/wrkgrp11/wg11_cpolicy.pdf

Kroeber, A. L. \& Kluckhohn, C. (1952). Culture: A Critical Review of Concepts and Definitions, New York: Random House., P.357.
La Porta, R., Lopez-De-Silanes, F., Shleifer, A. \& Vishny, R. W. (1998). "Law And Finance," Journal of Political Economy, 106(6), 11131156.

La Porta, R., Lopez-De-Silanes, F, Shleifer, A. \& Vishney, R. W. (2000). "Investor Protection and Corporate Governance," Journal of Financial Economics, 58(2), 3-27.

Li, J. \& Harrison, J. R. (2008). "Corporate Governance and National Culture: A MultiCountry Study," Corporate Governance, 8(5), 607-621.

Li, J. \& Harrison, J. R. (2008). "National Culture and the Composition and Leadership Structure of Boards and Directors," Corporate Governance: An International Review, 16(5), 375-385.

Lich, A. (2001). "The Mother of All Path Dependance: Toward a Cross Cultural Theory of Corporate Governance System," Delaware Journal of Corporate Law, 26(1), 147-205.

Licht, A. N., Goldschmidt, C. \& Schwartz, S. H. (2004). "Culture Rules: The Foundations of the Rule of Law and Other Norms of Governance," Journal of Comparative Economics, 35(4), 659-88.

Lopez-De-Silanes, F., La Porta, R., Shleifer, A. \& Vishney, R. (1997). "Legal Determinants of External Finance," Journal of Finance, LII (3), 1131-1150.

Mcclelland, P. L. \& O’Brien, J. P. (2011). "Transaction Cost Economics and Corporate Governanace: The Case of CEO Age and Finanacial Stake," Managerial and Decision Economics, 32, 141-158.

Millar, C. C, Eldomiaty, T. I, Choi, C. J. \& Hilton, B. (2005). "Corporate Governance and Institutional Transparency in Emerging Market," Journal of Business Ethics, 59(1), 163-174.

Mork, R., Shleifer, A. \& Vishny, R. (1988). "Management Ownership and Market 
Valuation," Journal of Financial Economics, 20(1-2), 293-315.

Okpara, J. 0. (2011). "Corporate Governance in a Developing Economy: Barriers, Issues, and Implications for Firms," Corporate Governance, 11(2), 184-199.

Okpara, J. O. \& Wynn, P. (2008). "Human Resource Management Practices in a Transition Economy: Challenges and Prospects," Managemnent Research News, 31(1), 57-76.

Reed, D. (2002). "Corporate Governance Reform in Developing Countries," Journal of Business Ethics, 37(3), 223-247.

Schwartz, S. H. (1999). "A Theory of Cultural Value and Some Implications for Work," Applied Psychology: An International Review, 48(1), 23-47.

Setiawan, A. (2007). "The Evaluation of Corporate Governance Practices in Indonesia: A Case Study," PhD thesis, School of Accounting and Finance, University of Wollongong, 2007. http://ro.uow.edu.au/theses/690.

Shleifer, A. \& Vishny, R. W. (1986). "Large Shareholders and Corporate Control," Journal of Polotical Economy, 94(3), 461-88.

Shleifer, A. \& Vishny, R. W. (1997). "A Survey of Corporate Governance," The Journal of Finance, 52(2), 737-783.

Sites, P. \& Taylor, B. (2001). Boards at Work: How Directors View Their Roles and Responsibilities, New York: Oxford University Press.

Thompson, B., Justin E. Levitov \& Patrick A. Miederhoff (1982). "Validity of the Rokeach Value Survey," Educational and Psychological Measurement, 42(3), 899-905.

Turnbal, S. (1997). "Corporate Governance: Its Scope, Concerns and Theories," Corporate
Governance : An International Review, 5(4), 180-205.

Williamson, O. E. (1996). The Mechanisms of Governance, New York: Oxford University Press. 